\title{
O JULGAMENTO DE ADOLF EICHMANN: A TENTATIVA DA DEFESA DE JUSTIFICAR O INJUSTIFICÁVEL
}

\section{THE JUDGMENT OF ADOLF EICHMANN; THE DEFENSIVE ATTEMPT TO JUSTIFY THE UNJUSTIFIABLE}

Luiz Henrique Lucas Barbosa*

\begin{abstract}
Resumo: O presente artigo se propõe a investigar os antecedentes que deflagraram a ascensão do nazismo na Alemanha da primeira metade do século XX. O desespero e a crise que tomaram os espíritos da população germânica conduziram os destinos da nação a reconhecer e mesmo apoiar parcialmente a Adolph Hitler e seus partidários. Dentre eles destacamos a Adolf Eichmann, um homem simples que se rendeu a toda a burocracia da máquina nazista e se apresentou como um cego observador dos mandamentos legais, mesmo que assim se tenha transformado em un frio assassino de judeus. Uma vez terminada a guerra, Eichmann fugiu para a América do Sul, vivendo escondido com sua família num subúrbio de Buenos Aires (Argentina). Ali foi reconhecido, capturado pelo "Mossad" e conduzido a Jerusalém, onde foi julgado e condenado à pena de morte. Este artigo se ocupa de investigar os argumentos da defesa e de apresentar sua recusa pela corte israelense. Não é nossa proposta buscar casos similares posteriores ao julgamento de Eichmann, mas apenas debater os argumentos levantados por seu advogado.
\end{abstract}

Palavras-chave: Alemanha Nazista. Eichmann. Defesa. Obediência. Lei.

Abstract: This article aims to investigate the background that deflagrated the rise of Nazism in Germany in the first half of the 20th century. The desperation and crisis that took the spirits of germanic people drove nation's destinies to recognize and even support in part Adolph Hitler and his partners. One of these was Adolf Eichmann, a simple man who surrendered himslef to all the bureaucracy of nazi machine and was presented as a blind observer of legal orders, even though if it changed him in a cold murderer of jews. Once the war ended, Eichmann fled to South America, living hidden with his family in a suburb of Buenos Aires (Argentina). There he was recognized, captured by "Mossad" and driven to Jerusalem, where he was tried and sentenced to death penalty. This article deals with investigating the arguments of Eichmann's defense and presenting its rejection by israeli court. It's not our intention to investigate similar cases, after Eichmann's judgement, but only to discuss the arguments raised by hir lawyer.

*Graduado em Direito pela Universidade do Estado do Rio de Janeiro, com Especialização em Direito Público e Processual Civil pela Universidade Gama Filho e Mestre em Direito Internacional dos Direitos Humanos pela Universidade Cândido Mendes. Graduado em Ciências Religiosas pela Pontifícia Universidade Católica do Rio de Janeiro e em Teologia pela Faculdade de Ciências, Educação e Teologia do Norte do Brasil (reconhecimento pelo MEC). Atualmente é aluno dos cursos intensivos do Doutorado em Direito Penal da Universidade de Buenos Aires e oficial de justiça na Seção Judiciária do Rio de Janeiro - SEMCI. Contato: luizhlbarbosa@ig.com.br. 
Keywords: Nazi Germany. Eichmann. Defense. Obedience. Law. 


\section{INTRODUÇÃO}

Otto Adolf Eichmann foi membro da SS nazista (organização paramilitar de proteção aos membros do Partido Nacional-Socialista Alemão). Uma das últimas atribuições dessa força policial foi justamente o funcionamento e as deportações para os campos de extermínio. Entre 19 de dezembro de 1939 e 24 de dezembro de 1944, Eichmann comandou o transporte de judeus para guetos e campos de concentração nazistas, quando então escapou da tomada de Budapest (Hungria) pelos soldados soviéticos, quase ao final da segunda guerra. Em 6 de julho de 1944 foram 437.000 judeus húngaros assassinados nesses campos.

Eichmann e sua família voltaram a Berlim e de lá foram viver escondidos na Áustria. Capturado pelos americanos, Eichmann escapou da prisão e, depois de atravessar diversos países da Europa com a ajuda do bispo Alois Hudal (católico austríaco e simpatizante do nazismo), há 14 de julho de 1950 ele chegou sozinho a Buenos Aires, com documentos falsos em nome de Ricardo Klement. A princípio foi viver em Tucumán. Em 1952 seus familiares chegaram à Argentina e foram para Buenos Aires. Em 1960 mudaram de endereço e foram para São Fernando, 20 km ao norte do centro da capital. Eichmann trabalhava então como chefe de departamento na fábrica da Mercedes-Benz.

Há 11 de maio de 1960, uma equipe do Mossad (serviço secreto de Israel) capturou Eichmann quando voltava para casa do trabalho e, perto da meia-noite do dia 20 do mesmo mês, todos embarcavam em um voo da El Al com destino a Israel. Desembarcaram em território israelense no dia 22. O sequestro de Eichmann gerou um forte protesto da Argentina e o Conselho de Segurança das Nações Unidas foi convocado prontamente. Depois de negociações, o impasse foi solucionado e Adolf Eichmann levado a julgamento ante o Tribunal Distrital de Jerusalém. A corte começou os trabalhos há 11 de abril de 1961 e prolatou a sentença em 12 de dezembro do mesmo ano, sentenciando Eichmann à morte por enforcamento. Há 10 de junho de 1962, depois de ver negados seus recursos, Adolf Eichmann foi executado em uma prisão de Ramla (Israel).

O embate entre defesa e acusação durante o julgamento transcorreu no campo do conflito entre a obediência cega à lei do Reich e a consciência de estar 
violando direitos humanos, como a vida e a dignidade da pessoa humana. Os tópicos que se seguem irão analisar os argumentos e a solução do caso.

\section{ALEMANHA: DA REPÚBLICA AO REICH}

Para compreender as acusações contra Eichmann, vejamos o que se passou na Alemanha da primeira metade do século XX.

\subsection{Origem do Caos Político e Econômico}

Quando a Primeira Guerra terminou (1918), os vencidos viram cair seus antigos impérios: Alemão, Austro-Húngaro e Turco-Otomano. Nos interesa em particular o primeiro deles.

Todas as vitórias políticas e o prestígio internacional que Otto von Bismarck conquistou para os alemães até fins do século XIX se evaporaram com a derrota bélica em 1918 e a consequente vergonha internacional. Em fins desse ano, o kaiser Guilherme II abdicou do trono e se exilou nos Países Baixos. Com o fim do império, se estabeleceu uma república em território alemão, denominada de República de Weimar, que durou de 1918 a 1933 (com o começo do regime nazista). Paul von Hindenburg foi o segundo presidente da república, eleito por duas vezes (1925 e 1932). Em 32 - por conselho de Franz von Papen - Hindenburg designou Adolf Hitler para chanceler e, assim, foi perdendo seu poder pouco a pouco, até sua morte em 1934. Hitler concentrou todos os poderes de Chefe de Estado e de Governo, assim permanecendo até sua morte em 1945.

A era de Weimar foi o tempo em que os alemães sofreram com escassez de alimentos, inflação alta, desemprego e muita instabilidade política. Os protestos populares eram frequentes e violentos nas ruas de Berlim e Munique. Um cenário propício ao surgimento do regime nazista, que fez Hitler prosperar com a imagem de salvador da nação. Paul Joseph Goebbels foi seu ministro da propaganda e o grande responsável por fazer com que os alemães apoiassem o Führer (guia) e sua ideologia de pureza da raça ariana. 
O sentimento antissemita já era bem consolidado na Áustria quando o Partido Nacional Socialista assumiu o poder na Alemanha (1933). Entretanto, não podemos tratar da política de extermínio racial durante a Segunda Grande Guerra antes de investigar as origens do antissemitismo, avaliando a questão judaica.

\subsection{A Questão Judaica}

O antissemitismo é um fenômeno muito mais complexo do que aparenta ser. Ele não surgiu simplesmente do sentimento de repulsa ao povo hebreu pelos membros do nacional-socialismo alemão. Não foram os nazistas que inspiraram o antissemitismo, mas o antissemitismo que ajudou a inspirar os nazistas.

A teoria da conspiração judaica ou Reino Secreto de Judá, muitas vezes apresentada sob a alcunha de "Protocolos dos Sábios de Sião", nutriu o imaginário de muitos antissemitas, que se valiam desse argumento para defender a necessidade de combater o poder descontrolado em mãos judaicas, da mesma forma que a teoria da conspiração romana ou Roma Secreta serviu para atacar a Igreja Católica Romana. Os Protocolos dos Sábios de Sião ou Protocolos de Sião são um texto surgido originalmente em idioma russo, forjado em 1897 pela Okhrana (polícia secreta do tzar Nicolau II), que descrevia um suposto projeto de conspiração para que os judeus alcançassem a "dominação mundial". O texto foi traduzido do original para vários idiomas e tem o formato de uma ata que teria sido composta pelo participante de um Congresso realizado a portas fechadas, em uma assembleia na Basileia (1807), onde um grupo de sábios judeus e maçons se reuniram para estruturar um esquema de dominação do mundo. Nesse evento foram formulados planos como: usar uma nação europeia que servisse de exemplo para as demais que se atrevessem a atravessar o caminho dessa dominação, controlar o ouro e as pedras preciosas, criar uma moeda amplamente aceita e que estivesse sob o seu controle, confundir os "não-escolhidos" com números econômicos e físicos e, principalmente, gerar caos e pânico capazes de fazer com que os países criassem uma organização supranacional capaz de interferir em países rebeldes.

Numerosas investigações repetidamente provaram tratar-se de um embuste, especialmente uma série de artigos do periódico inglês The Times of London, de 16 a 
18 de agosto de 1921, o que leva a crer que muito do material utilizado no texto era plágio de sátiras políticas existentes, as quais não tematizavam a questão antissemita. Segundo essas investigações, a base da história dos Protocolos, como circula desde então, foi criada por um novelista alemão antissemita, denominado Hermann Goedsche, que usou o pseudônimo de Sir John Retcliffe. A contribuição original de Goedsche consistiria na introdução dos judeus como conspiradores para a conquista do mundo. O periódico norte-americano The New York Times republicou os textos em 4 de setembro de 1921.

Adolf Hitler e seu Ministério da Propaganda citaram os Protocolos para justificar a necessidade do extermínio de judeus, o que já havia sido pleiteado mais de 10 anos antes. Para a retórica nazista, a "conquista do mundo pelos judeus" descoberta pelos russos em 1897 - estava obviamente sendo ainda levada a cabo 33 anos depois. A utilização dos Protocolos por Hitler pode ser apreciada na seguinte tradução do "Mein Kampf", capítulo XI, Nação e Raça:

[...] até que ponto toda a existência desse povo é baseada em uma mentira continuada, incomparavelmente exposta nos Protocolos dos Sábios de Sião, tão infinitamente odiado pelos judeus. Eles são baseados em um documento forjado, como clama o periódico Frankfurter Zeitung (itálico nosso) toda semana: é a maior prova de que eles são autênticos. $O$ que muitos judeus fazem inconscientemente, aqui é exposto de forma consciente. $E$ é isso que importa. É completamente indiferente de qual cérebro judeu essa revelação se originou; o importante é que, com uma certeza positiva e terrível, eles revelam a natureza do povo judeu e expõem seus contextos internos bem como seus objetivos finais. Todavia, a melhor crítica aplicada a eles é a realidade. Qualquer um que examine o desenvolvimento histórico dos últimos 100 anos, do ponto de vista desse libro, vai entender de uma vez os gritos da imprensa judaica. Agora que esse livro se tornou uma propriedade do povo, a ameaça judaica é considerada interrompida (HITLER, 1925, pp. 307-308 apud GOES, 2015).

Hannah Arendt, filósofa alemã de origem judaica, explica como cresceu o antissemitismo na Europa:

Durante mais de cem anos o antissemitismo havia, lenta e gradualmente, penetrado em quase todas as camadas sociais em quase todos os países europeus, até emergir como a única questão que poderia unir a opinião pública. Foi simples como ocorreu esse processo: cada classe social que entrava em conflito com o Estado se tornava antissemita, porque o único grupo que parecia representar o Estado, identificando-se com ele servilmente, eram os judeus (ARENDT, 1989, p. 45). 
Aqueles que desejavam lançar-se na política e reunir os votos dos descontentes, logo se apresentavam como antissemitas, porque, assim, acreditavam estar posicionando-se contra tudo o que se relacionava com o poder governante. Nesse sentido também afirma Hannah Arendt:

[...] era necessário ingressar na área da luta contra os judeus para conquistar o poder político. Fingiam estar lutando contra os judeus exatamente como os trabalhadores lutavam contra a burguesia, e, atacando os judeus, que apresentavam - de acordo com a ideia geral - como detentores do poder por detrás dos governos, agrediam abertamente 0 próprio Estado, catalisando assim todos os descontentes e frustrados (ARENDT, 1989, p. 60).

Posteriormente, os nazistas souberam aproveitar muito bem o sentimento antissemita arraigado nos povos germânicos. Para Hannah Arendt:

\begin{abstract}
A mais eficaz ficção da propaganda nazista foi a história de uma conspiração mundial. Concentrar-se em propaganda antissemita era expediente comum dos demagogos desde fins do século XIX, e muito difundido na Alemanha e na Áustria na década de 1920. Quanto mais constantemente os partidos e órgãos de opinião pública evitavam discutir a questão judaica, mais a chusma se convencia de que os judeus eram os verdadeiros representantes das autoridades constituídas, e de que a questão judaica era o símbolo da hipocrisia e da desonestidade de todo o sistema. O verdadeiro conteúdo da propaganda antissemita do pós-guerra [depois de 1918] não era monopólio dos nazistas nem particularmente novo e original. Mentiras acerca de uma conspiração mundial judaica haviam sido veiculadas desde o Caso Dreyfus, e se baseavam na inter-relação e interdependência do povo judeu disseminado por todo o mundo. Mais antigas ainda são as noções exageradas do poder mundial dos judeus; as encontramos em fins do século XVIII, quando a estreita relação entre os comerciantes judeus e os Estadosnações se tornou visível (ARENDT, 1989, p. 403).
\end{abstract}

Em discurso realizado em Kharkov, Heinrich Himmler recordava aos líderes da SS de que esses eram os primeiros a efetivamente resolver pela ação o problema do sangue. Para o chefe da polícia nazista "sangue" não era entendido como mero antissemitismo, pois o sentimento antissemita "é a mesma coisa que catar piolhos. Catar piolhos não é uma questão de ideologia; é uma questão de limpeza". Ainda para Himmler, a questão do sangue era a memória de seu próprio valor e uma recordação que mantinha unido o povo alemão. 


\title{
2.3 Extermínio
}

A radicalização do ideal da antiga seleção racial pode ser verificada em todas as fases da política nazista. Os primeiros exterminados foram os "judeus puros", seguidos dos "meio-judeus" e dos "um-quarto-judeus". Os nazistas não desejavam em nenhuma hipótese ver o território do país despovoado, o que faria inserir a Alemanha no panorama crítico do desemprego mundial pós 1929. Quando os trabalhadores forçados foram levados do leste europeu para garantir a produção das indústrias alemãs, o quadro se tornou favorável à eliminação em massa de indivíduos indesejáveis, sobretudo judeus e eslavos.

Quanto à política de extermínio dos inimigos do regime, cabe esclarecer que - ainda que os campos de concentração estivessem a cargo da SS no período mais terrível da eliminação de prisioneiros - Hitler parece ter sido o mentor das piores atrocidades praticadas. Hannah Arendt informa que:

\begin{abstract}
Já restou provado, por meio de numerosos documentos, que era o próprio Hitler - e não Himmler, nem Bormann, nem Goebbels - quem sempre tomava a iniciativa das medidas realmente "radicais"; que essas medidas eram sempre mais radicais que aquelas propostas por seus seguidores imediatos; que até Himmler ficou horrorizado quando recebeu a incumbência da "solução final" da questão judaica. (ARENDT, 1989, p. 425, nota 89).
\end{abstract}

Lionel Richard (1988) segue a opinião de que nem mesmo a relevância política de Hitler teria sido suficiente para o sucesso macabro dos campos de concentração, se não houvesse ocorrido a colaboração técnica de dezenas de milhares de funcionários zelosos da extinta república e a concordância ou adesão passiva de milhões de cidadãos desesperados com a ineficácia do regime republicano. Entendemos que Eichmann estaria inserido nesse contingente de colaboradores.

A tortura física e psicológica foi uma prática tão comum nos campos de concentração nazistas que alguns fatos acabaram por tornarem-se conhecidos em todo o mundo, ainda que muito do que ali ocorreu só viesse ao conhecimento público com o encerramento da guerra e o retorno dos sobreviventes à sua condição anterior. Para Hannah Arendt a tortura é parte essencial de toda polícia totalitária e 
de seu aparato judicial. Trata-se de um tipo de tortura com objetivos definidos e racionais, apresentando limites pré-estabelecidos. Se tortura o prisioneiro diariamente até que fale ou aja de acordo com os interesses dos torturadores; porém, se dentro de um tempo estabelecido ele nada contar, é automaticamente eliminado.

Tão pronto Hitler se tornou chanceler em 1933, e já nos anos seguintes a lei e a constituição - que permanecia a mesma da República de Weimar - foram desobedecidas inúmeras vezes por ele e pelos membros do NSDAP, de forma que muitos juízes afirmavam naquela época que "Hitler é a lei!". Hermann Göring declarou aos promotores prussianos em 12 de junho de 1934 que a "vontade do Führer e a lei são a mesma coisa". O próprio Hitler, depois do expurgo em massa de seus inimigos na Noite das Facas Longas, em seu discurso no Reichstag, se denominou o "juiz supremo do povo alemão". Hitler tinha inclusive o direito de revogar os processos criminais.

O registro de todas as decisões dos tribunais para os acusados de atacar o Partido Nazista era mandado para o deputado Rudolf Hess que, se considerasse a sentença muito branda, condenava muitas vezes a pessoa a ser levada a um campo de concentração ou a sentenciava à morte. Os juízes eram estimulados a desobedecer a lei em favor do nazismo. O Dr. Hans Frank, Comissário de Justiça e Líder Jurídico do Reich, disse aos juristas em 1936:

\begin{abstract}
A ideologia nacional-socialista é o fundamento de todas as leis básicas. Frente ao nacional-socialismo não há lei Independiente. Ante qualquer decisão que tomeis perguntai a vós mesmos 'Como decidiria o Führer em meu lugar? ' Em toda decisão, preguntai 'Será essa decisão compatível com a consciência nacional-socialista?'. (FORTES, 2009).
\end{abstract}

Toda perseguição racista continuaria em intervalos irregulares até o programa da 'Noite dos Cristais Quebrados' e o incêndio das sinagogas do dia 9 de novembro de 1938. A Noite dos Cristais Quebrados entraria para a História como o início do "holocausto" que provocou a morte de seis milhões de judeus na Europa até fins da $2^{\text {a }}$ Guerra Mundial. Essa noite, de 9 para 10 de novembro de 1938, na Alemanha e na Áustria, foi marcada pela destruição de símbolos, sinagogas, comércios e casas de judeus. 
Então, a perseguição aos indesejados do regime foi gradual: primeiro veio a emigração forçada; depois a deportação; e finalmente a execução - ou, melhor, extermínio - nos campos de concentração como Dachau; Sobibor, Treblinka e Auschwitz. Em sua obra "História da Solução Final, uma indagação das etapas que levaram ao extermínio dos judeus europeus", Daniel Rafecas (2014, p. 213-265) trata desses e outros campos de extermínio nazistas.

Encerramos aqui o primeiro capítulo, crendo que as informações são suficientes para compreender como o nacional-socialismo pode encontrar espaço e apoio na Alemanha e na Áustria e por que a vontade de Hitler se tornou lei inquestionável na consciência coletiva.

\section{O CASO EICHMANN: A DEFESA}

Citados os fatos históricos, passemos a apreciar os argumentos da defesa, patrocinada pelo advogado alemão Robert Servatius, com assistência de Dieter Wechtenbruch e participação ativa do próprio Eichmann.

Os bastidores do julgamento de Eichmann em Jerusalém são conhecidos nossos graças ao trabalho da filósofa judia-alemã Hannah Arendt, que atuou como correspondente da revista The New Yorker. Posteriormente ela publicou, em 1963 (edição original), um livro denominado "Eichmann em Jerusalém, um relato sobre a banalidade do mal" (ARENDT, 1999), que apresentou ao mundo a acusação suportada pelo nazista, os fortes testemunhos prestados por aqueles que foram submetidos às atrocidades nos campos de concentração, assim como o comportamento frio do réu e a tentativa da defesa de justificar o injustificável. Ainda que a filósofa tenha feito um relato imparcial do julgamento, apresentando uma realidade onde todo inimigo da raça ariana era tratado como menos que um objeto ou seja, o emprego do mal como algo comum à consciência nazista, sem dramas ou ressentimentos -, ela não se colocou jamais contra seu povo. Entretanto, muitos foram os judeus - mesmo amigos - que a acusaram de ser traidora da religião, por amenizar as ações bárbaras de Adolf Eichmann.

A base da defesa de Eichmann foi a de que ele se limitou a obedecer ordens legais e superiores. Segundo interrogatório do próprio réu, na Alemanha nazista 
ninguém se atrevia a dizer não às ordens do Führer. Como policial (chegou ao posto de tenente-coronel) que servia na SS, Eichmann obedecia a uma hierarquia cega, que recebia com normalidade e tranquilidade a autoridade dos mandatários nazistas e não se desviava um ponto sequer das leis e demais normas decretadas pelo alto comando do regime.

Para Eichmann, a obediência cega - ou "obediência cadavérica" como ele mesmo dizia - era a razão que levava um homem a obedecer às leis mais que às ordens superiores. E, por isso, não era possível ver nada de mal em sua conduta. Ele citou o nome de Kant para embasar sua teoria de que não se devem criar exceções às leis. Sob tal filosofia, leis são feitas para serem cumpridas; são leis, não exceções. Porém Hannah Arendt cita que Eichmann teve dois episódios em que violou a hierarquia e as leis e atendeu a interesses particulares em favor de judeus. Por isso, aos olhos dos juízes israelenses, Eichmann tinha sim consciência da diferença entre certo e errado. $O$ réu tentou convencer a corte de que ele pedira desculpas a seus superiores por essas exceções em favor dos judeus, mas não foi suficiente para convencer os magistrados.

Também pesou contra Eichmann suas ordens para que os prisioneiros judeus marchassem a pé de Budapest até a Áustria (em 1944), pois Himmler havia desativado o campo de Aushwitz e todo o sistema de transporte (por trem) de prisioneiros. O comandante supremo da SS queria tratar bem os judeus ao final da guerra, pois almejava obter um acordo com os Aliados; assim que a determinação de Eichmann se deu por sua própria responsabilidade. Hannah Arendt cita que Himmler teve uma discussão com Eichmann porque este não obedeceu suas ordens de tratar bem aos judeus e tomou tal iniciativa, contra o empenho de alguns nazistas de interromper com a "solução final". Portanto, era difícil crer que Eichmann tivesse sido um mero cumpridor de ordens e leis.

Hannah Arendt (2013, p. 158) cita que, antes das ordens de Himmler de desativar Auschwitz, Eichmann organizou o transporte de 147 trens, conduzindo 434.351 judeus húngaros desde Budapest até aquela cidade polonesa e que, por isso, as câmaras de gás do citado campo quase não conseguiram funcionar devidamente. Era claro que Eichmann não foi o inocente que pretendia apresentar a 
defesa. Hannah Arendt cita também a participação decisiva de Eichmann para o sucesso da shoah:

\begin{abstract}
Em todos os momentos, Eichmann fez o máximo para tornar final a Solução Final - isso não estava em discussão. A questão era apenas se isso constituía prova de seu fanatismo, seu ódio ilimitado aos judeus, e se ele havia mentido à polícia e cometido perjúrio no tribunal ao afirmar que sempre obedeceu ordens. Nenhuma outra explicação ocorreu aos juízes, que tanto se esforçaram para compreender o acusado e o trataram com uma consideração, com uma humanidade autêntica e radiante, tais como ele provavelmente jamais encontrou em sua vida (ARENDT, 1989, p.163).
\end{abstract}

Outra aberração alegada por Eichmann para justificar sua obediência cega era a autoridade suprema de Hitler como única lei vigente. Em palavras de Hannah Arendt:

\begin{abstract}
Em Jerusalém, confrontado com provas documentais de sua extraordinária lealdade a Hitler e à ordem do Führer, Eichmann tentou muitas vezes explicar que durante o Terceiro Reich "as palavras do Führer tinham força de lei" [...] o que significava, entre outras coisas, que uma ordem vinda diretamente de Hitler não precisava ser escrita. Ele tentou explicar que, por isso, nunca tinha pedido uma ordem escrita a Hitler (nenhum documento relativo à Solução Final jamais foi encontrado) [...] Sem dúvida era um estado de coisas fantástico, e bibliotecas inteiras de comentários jurídicos "abalizados" foram escritas demostrando que as palavras do Führer, seus pronunciamentos orais, eram a lei do mundo. Dentro desse panorama "legal", toda ordem contrária em letra ou espírito à palavra falada por Hitler era, por definição, ilegal (ARENDT, 1989, p.165).
\end{abstract}

O complexo na argumentação de Eichmann está em que ele não se pautou somente nas ordens de Hitler (o que caracterizaria, em tese, uma estrita obediência hierárquica), senão que cumpria a lei e essa se confundia com a vontade do Führer. A própria Hannah Arendt identifica que não pairava "uma bandeira negra" da ilegalidade (como algo proibido) sobre a cabeça de Eichmann. Para ele, todas as suas ações estavam respaldadas pela lei do Terceiro Reich. Eichmann era mais que um policial cumpridor de ordens; era um cidadão observador de leis. Não the importava se o direito positivo da Alemanha entre 1933 e 1945 era contrário às básicas noções do direito natural de preservação de qualquer vida, inclusive a dos judeus. Leis eram leis; não cabiam exceções. Assim como um soldado que não acata a ordens de seu comandante porque as compreende contrárias à lei, Eichmann também não cumpriu ordens de Himmler (de parar com a Solução Final) pois Hitler era a lei e, por isso, estava acima de Himmler. 

consciência cívica, ainda que obtusa, de Eichmann:

\begin{abstract}
Eichmann, muito menos inteligente e sem nenhuma formação, percebeu ao menos vagamente que não era uma ordem, mas a própria lei que os havia transformado a todos em criminosos. Uma ordem era diferente da palavra do Führer porque a validade desta última não era limitada no tempo e no espaço - a característica mais notável da primeira. Essa é também a verdadeira razão pela qual a ordem do Führer para a Solução Final foi seguida por uma tempestade de regulamentos e diretivas, todos elaborados por advogados peritos e conselheiros legais, não por simples administradores; essa ordem, ao contrário de ordens comuns, foi tratada como uma lei. Nem é preciso acrescentar que a parafernália legal resultante, longe de ser um mero sintoma do pedantismo ou empenho alemão, serviu muito eficientemente para dar à toda a coisa sua aparência de legalidade (ARENDT, 1989, p.167).
\end{abstract}

E, encerrando as considerações da filósofa judia, observemos suas reflexões acerca da banalização e indiferentismo ante o mal praticado pelos nazistas:

\begin{abstract}
E assim, como a lei de países civilizados pressupõe que a voz da consciência de todo mundo dita "Não matarás", mesmo que os desejos e inclinações do homem natural sejam as vezes assassinos, assim a lei da terra de Hitler ditava à consciência de todos: "Matarás", ainda que os organizadores dos massacres soubessem muito bem que o assassinato era contra os desejos e inclinações normais da maioria das pessoas. No Terceiro Reich, o Mal perdera a qualidade pela qual a maior parte das pessoas o reconhecem - a qualidade da tentação. Muitos alemães e muitos nazistas, provavelmente a maioria absoluta deles, deve ter sido tentada a não matar, a não roubar, a não deixar seus vizinhos partirem para a destruição (pois eles sabiam que os judeus estavam sendo transportados para a destruição, é claro, ainda que muitos possam não ter sabido dos detalhes terríveis), e a não se tornarem cúmplices de todos esses crimes, tirando proveito deles. Porém, Deus sabe como eles tinham aprendido a resistir à tentação (ARENDT, 1989, p. 167).
\end{abstract}

Terminado o relato da tese da defesa, passemos à sentença condenatória e por que não foi a vencedora.

\title{
4 A SENTENÇA DE JERUSALÉM
}

Apesar de arguir sua inocência ante a estrita obediência ao ordenamento legal do Reich, Eichmann foi acusado de haver atuado com consciência e vontade livres, conhecedor do mal que praticava aos judeus e até mesmo sem obedecer às ordens de seus superiores imediatos, como quando Himmler determinou que cessassem os procedimentos para a Solução Final da causa judaica. Portanto, ao 
confrontar seu dever ante a lei com aquele de proteger a vida, a integridade e a dignidade de todos os prisioneiros sob sua tutela, ele não teve dúvidas em sobreestimar o primeiro.

Segundo Daniel Rafecas, a conduta reprovável de Adolf Eichmann pode ser estudada dentro da denominada autoria mediata pelo emprego de um aparato de poder organizado:

O tema em questão irrompeu na cena da dogmática penal alemã em 1963, graças a um trabalho de Claus Roxin, a partir dos fundamentos da sentença condenatória aplicada em fins de 1961 contra o criminoso nazista Adolf Eichmann, na cidade de Jerusalém (RAFECAS, 2015, p. 206).

No magistério de Rafecas, essa questão não apresentava antecedentes e cuidava de investigar como deveriam responder os mandantes das atrocidades perpetradas contra os judeus; pessoas que não mancharam suas mãos com o sangue de inocentes, mas que foram essenciais para o delito. Havia uma cadeia, como uma pirâmide, onde no ápice se encontravam os detentores do poder, os mandantes; ao passo que na base estavam os executores. Se os subalternos eram os que de fato executavam os crimes, a ausência deles não impediria a continuidade delitiva, pois que os chefes nazistas haviam sempre de ter alguém para fazer cumprir as ordens de torturar e eliminar a todos os indesejáveis do regime. Essa estrutura delitiva se denomina "criminalidade estatal". E aqui não há que falar em erro de tipo ou de proibição do executor, que atua movido por uma cadeia de comando. $\mathrm{O}$ autor mediato sabe que, ao acionar o dispositivo, alguém - conhecido ou não - irá cumprir a ordem. Se um executor se nega a fazê-lo, outro o fará em seu lugar, pois que há uma fungibilidade intrínseca na cadeia hierárquica. Não se pode dizer que a autoridade atuou com engano ou coação, senão que somente determinou algo e um subalterno deveria cumpri-lo.

Segundo Roxin, citado por Rafecas (2015, p. 207), quando agentes públicos cometem delitos - baseados em ordens do Estado - os mandantes serão autores mediatos, pois que deram o comando, exercendo controle sobre a organização hierárquica e, por isso, apresentam mais responsabilidades que os executores diretos. Ou seja: 
[...] tratando-se de uma organização criminal desta envergadura, a realização do delito de modo algum depende dos executores singulares. Eles somente ocupam uma posição subordinada no aparato de poder, são intercambiáveis, e não podem impedir que o homem de trás, o "autor de escritório", alcance o resultado, já que é este quem conserva em todo momento a decisão acerca da consumação dos delitos planificados.

Como sustenta o jurista de Munique, se, por exemplo, algum agente se nega a executar uma detenção ilegal, isto não implica o fracasso do delito (há aqui uma primeira distinção com a instigação). Imediatamente, outro ocuparia seu lugar e realizaria $o$ ato criminal, sem que desta incidência chegue a ter conhecimento o homem de trás, que de todas formas ignora quem é o executor individual. 0 homem de trás, pois, controla o resultado típico através do aparato, sem levar em consideração a pessoa que, como executor, entra em cena mais ou menos casualmente. $O$ homem de escritório tem o "domínio" propriamente dito e, portanto, é autor mediato (RAFECAS, 2015, p. 208).

Estamos ante uma terceira modalidade de autoria mediata que difere do erro e da coação. A pedra basal deste tipo de autoria mediata está apoiada na fungibilidade dos executores (dentro de um aparato organizado de poder), que são pessoas anônimas e substituíveis. Em palavras de Claus Roxin (RAFECAS, 2015, p. 208): eles são "engrenagens cambiáveis na máquina do poder".

Por essas lições, já nos seria possível fazer a seguinte pergunta: Na cadeia hierárquica nazista, Adolf Eichmann seria mandante ou executor? Posto que chegou a um alto grau de oficial (tenente-coronel), como dizer que não partiam dele as ordens de transporte e execução? O que dissemos no tópico anterior, ao cuidar dos argumentos da defesa, foi que Eichmann nutria uma admiração incontrolável por Hitler, mas se justificava ante a corte que Ihe julgava, alegando que cumprira cegamente a todas as leis do Reich. Porém, vimos também que, quando ordenado por Himmler a cessar as crueldades contra os judeus - mesmo depois de desativado o campo de Auschwitz - Eichmann pôs em marcha um grupo de judeus, os fazendo caminhar desde a Hungria até a Áustria (210 quilômetros), o que demonstrava sua aversão àqueles prisioneiros.

Óbvio que Hitler como Führer, Himmler como comandante da SS ou Höss como comandante de Auschwitz-Birkenau poderiam a qualquer momento substituir Eichmann em suas funções no serviço de transporte de presos para os guetos e campos de concentração nazistas. Sob este ponto de vista, Eichmann seria um servidor fungível e, portanto, um mero executor de ordens. Entretanto, quando Hitler já não tinha mais controle sobre o leste europeu, e quando Himmler fechou 
Auschwitz-Birkenau e determinou que se tratasse bem aos judeus, a quem Eichmann obedeceu senão que somente à sua consciência e a seus desejos mais bizarros? Dessa forma, não seria absurda a alegação de que, de alguma forma, Eichmann detinha liberdade suficiente para atuar, independente da cadeia hierárquica à qual estava subordinado. Não era um mero cúmplice, tampouco um burocrata do regime, como tentou convencer aos três juízes em Jerusalém. Também não estava sob estado de erro ou coação. Assim que não se pode alegar em seu favor a estrita obediência hierárquica superior.

Por outro lado, sustentou sua irrestrita observância às leis do Reich. Aqui nos cabe outros questionamentos: Alguém pode alegar obediência cega a um ordenamento legal que viola flagrantemente os mais fundamentais direitos humanos? E também: a existência de um autor mediato no aparato estatal organizado elimina qualquer responsabilidade do executor? Para responder à primeira pergunta, citamos o magistério de Daniel Rafecas:

[...] é importante deixar assentado que, conforme a doutrina especializada nesta questão, da estrutura organizativa de todo aparato de poder se depreende que este só pode dar-se ali quando funcione como uma totalidade fora da ordem jurídica, dado que, se se mantem dentro do Estado de Direito com todas as suas garantias, a ordem de executar ações puníveis não serve para fundamentar o domínio nem a vontade do poder do inspirador - pois em tal contexto deve esperar-se que ditas ordens criminais não sejam obedecidas pela regra geral (RAFECAS, 2015, p. 209).

Então, se Eichmann tivesse atuado dentro de um Estado regular de direito, não poderia dizer que o fazia para obedecer a ordens superiores e legais. Porém, a Alemanha nazista era um Estado Totalitário. De fato, já dissemos que Eichmann sabia que o que fazia era contra os mais basilares direitos humanos (pois atendeu a pedidos particulares em favor de judeus), mas não cessou com as deportações, prisões e extermínios enquanto Ihe foi possível. No mesmo momento histórico, outros alemães diziam não - expressa ou tacitamente - aos desvarios dos governantes. Por todo esse embate de argumentos, ainda que a ditadura fosse clara, nos parece bastante plausível que Eichmann poderia ter se negado a persistir com a solução final.

A resposta ao segundo questionamento também a encontramos nas lições de Rafecas: 
Por último, deve pôr-se de ressalto que a aplicação desta teoria em nada remove o enquadramento, como autor direto, do executor: "Dado que a autoria imediata do executor e a mediata do sujeito de trás se baseiam em requisitos ou condições distintas - uma no caráter de mão própria de sua atuação, a outra no controle ou manejo do aparato -, podem lógica e teleologicamente coexistir perfeitamente" (RAFECAS, 2015, p. 209).

Portanto, se Eichmann era de fato um fiel servo da lei - e esta se confundia com a pessoa de Hitler -, nem por isso ele deixava de ser o autor mediato dos crimes de lesa humanidade.

Se classificarmos o comportamento de Eichmann como estrito cumprimento do dever legal, como ele sustentou em sua defesa, teremos de investigar os elementos objetivos e subjetivos que compõem essa modalidade de causa de justificação. Objetivamente falando, parece que ele atendia às exigências, pois que se apresentava como um alemão que obedecia às ordens legais, mesmo que inumanas. E, sendo ele um membro da SS, sob juramento de fidelidade ao Führer, não se esperava nada diferente de suas condutas. Porém, subjetivamente, se pode dizer que Eichmann só desejava cumprir as leis ou poderia ter desejos íntimos de exterminar os judeus, já que provamos no primeiro tópico que essa era uma identidade cultural dos muitos europeus, sobretudo dos povos germânicos? Não se esqueça que Hannah Arendt (2013, p. 165) menciona que, depois de cessarem as atividades de transporte e extermínio de judeus, Eichmann foi enviado para cuidar da luta contra as igrejas e que não teve habilidade para tanto. Nos parece que eliminar judeus era um passatempo para Eichmann; não uma mera obrigação.

Ao tratar de antijuridicidade, Rogério Greco menciona o estrito cumprimento do dever legal como causa de justificação disposta no Direito Penal brasileiro. Contudo, citando a Zaffaroni e Pierangeli, recorda a questão da tipicidade conglobante e seus efeitos sobre a citada modalidade de justificação. No tópico 9.2 de seu livro, Rogério Greco analisa o estrito cumprimento do dever legal como causa de exclusão da ilicitude ante a tipicidade conglobante. Para ele:

Com a tipicidade conglobante se quer encurtar o estudo do crime, resolvendo, em algumas hipóteses, problemas que seriam analisados fora do estudo do tipo. Isso se dá, por exemplo, nos casos em que o agente atua amparado pelo estrito cumprimento do dever legal (GRECO, 2007, p. 273). 
Assim, para os que tentam defender a suposta "consciência normativa" de Eichmann, suas condutas poderiam mesmo ser atípicas, pois que não haveria a tipicidade conglobante junto à tipicidade formal. As normas ordinárias se chocavam com as excepcionais na consciência do réu.

E, para encerrar a análise da antijuridicidade, trazemos a opinião de Carlos Creus:

\begin{abstract}
Tenhamos presente que para não poucos tratadistas a obediência devida é um caso de justificação. Claro que quando a ordem é legítima, nenhuma dúvida cabe de que se trata de um atuar justificado do executor, mas porque ele leva a cabo uma ação em si justificada; todavia, o problema se coloca a propósito da juridicidade da execução da ordem ilegítima. Para considerar justificante a obediência devida se pensou em uma presunção de juridicidade da ordem dada dentro dos limites da competência do superior, ou considerando que se dá quando por erro o superior emitiu a ordem crendo que funcionavam as condições jurídicas que a dotavam de legitimidade etc. Sem dúvida, prima na doutrina contemporânea o critério de que não se trata de uma justificante, senão de uma situação de inculpabilidade, ainda que as razões para seguir esse critério não sejam uniformes (CREUS, 2017, p. 313).
\end{abstract}

Como é possível depreender de tudo o que dissemos neste tópico, a teoria do delito demonstra a fragilidade da argumentação a favor de Adolf Eichmann. Assim que, completadas as sessões da corte de Jerusalém, os três juízes condenaram o réu ao castigo capital e ele foi enforcado há $1{ }^{\circ}$ de junho de 1962.

Seu advogado (Dr. Servatius) apelou da sentença, alegando ilegalidade da jurisdição e das leis que condenaram a Eichmann, mas o Supremo Tribunal de Israel rechaçou a apelação. Estamos de acordo que a regra internacional do locus delicti comissii não foi obedecida. Independentemente das crueldades perpetradas por Adolf Eichmann e os demais nazistas, não se pode jamais abandonar conquistas normativas que estabelecem a sede de uma jurisdição. $E$, obviamente, a forma como Israel sequestrou, processou, condenou e executou Eichmann não se deu pela via legal.

Como os julgamentos de Nuremberg foram levados a termo pelos Aliados, havendo muitos nazistas que saíram ilesos - como os que fugiram e viveram anônimos na América do Sul ou os que se suicidaram ou morreram antes da execução da pena - chegava ao fim o antigo desejo de ver algum dos responsáveis pela shoah condenado pelos próprios judeus. 


\section{CONCLUSÃO}

Este trabalho buscou - através de uma breve revisão bibliográfica investigar o julgamento no caso Adolf Eichmann, seus antecedentes, sua defesa e a decisão da Corte de Jerusalém, baseando-se na análise da teoria do delito. Não havia qualquer pretensão de esgotar os fatos ou ampliar o campo de pesquisa para inserir comparações com outras tantas autorias mediatas para crimes contra a humanidade, como os atos militares e paramilitares da Guerra da Bósnia ou os massacres tribais de Ruanda por exemplo. Embora esses conflitos do século XX não tenham sido abordados em nossa pesquisa, entendemos importante deixar claro que poderiam ser investigados em outro trabalho, não sendo a proposta atual. A finalidade do artigo sempre foi a de proporcionar subsídios para novos estudos a partir dele, talvez de novas gerações que não conviveram com os frutos imediatos da segunda guerra mundial. Muito provavelmente Eichmann seja desconhecido de muitos alunos do Direito e a banalidade do mal atribuída a ele por Hannah Arendt possa inspirar novos artigos que trabalhem também a intolerância religiosa e fundamentalista de grupos como o Estado Islâmico e o Boko Haram. Muito em breve pretendemos escrever um artigo com tal comparação.

O julgamento de Eichmann teve início há 11 de abril de 1961. Ele foi acusado ante a Lei dos Colaboradores Nazistas (1950), sendo indiciado por quinze crimes, inclusive os de lesa humanidade contra os judeus e por associar-se a uma organização criminosa para eliminar pessoas indesejáveis ao regime. O julgamento foi presidido por três juízes israelenses: Moshe Landau, Benjamin Halevy e Yitzak Raveh. O promotor que acusou Eichmann foi Gideon Hausner, assistido por Gabriel Bach e por Yaakov Bar-Or. A defesa do réu estava sob a incumbência de Robert Servatius e Dieter Wechtenbruch, havendo também alguma participação do próprio Eichmann em determinados momentos.

Em suma, a promotoria buscou demonstrar um homem frio, conhecedor de tudo o que ocorria no território alemão ou sob sua ocupação. Para os acusadores, Eichmann conhecia bem os detalhes e sabia que estava praticando crimes de lesa humanidade, ainda que estivesse sob ordens de superiores e submetido a um regime totalitário instrumentalizado por um sistema normativo de exceção. Por isso, foi 
pedido o castigo capital para o réu. Muitas testemunhas que foram vítimas de Eichmann e sobreviveram foram a Jerusalém para declarar e apontar o dedo para aquele que tirara tantas vidas, somente pela banalidade do mal como bem disse Hannah Arendt.

Por outro lado, a defesa embasou seus argumentos em que Eichmann atuou dentro de um sistema de normas onde a lei era o próprio Hitler. Tudo o que o réu havia realizado, ele o fez atendendo a ordens superiores, sobretudo a determinações legais de uma época e um lugar. Um cidadão deve estar atento às ordens que deve cumprir e assim Eichmann atuou, como todo bom alemão deveria fazê-lo. Por isso, seria possível defender que Eichmann teria agido sob o estrito cumprimento do dever legal. Mas também não se pode esquecer que as atrocidades nazistas foram crimes de lesa humanidade, perfeitamente perceptíveis por qualquer pessoa com inteligência mediana, inclusive por um integrante da SS. Nem erro, nem coação, nem justificação foram capazes de legitimar a conduta de Eichmann.

Nada que disse a defesa foi capaz de convencer aos três juízes da corte israelense, os quais condenaram Adolf Eichmann à pena de morte. $E$, mesmo que se alegue a autoria mediata da cúpula do partido nacional-socialista alemã (os membros do governo de Hitler), de fato Eichmann manchou suas mãos com o sangue hebreu. Ele foi o executor imediato dos crimes, a engrenagem que fez mover a máquina de destruição nazista.

Ainda quando teve a oportunidade, Eichmann não cessou suas atividades delitivas. Por isso, nenhuma de suas palavras convenceu os juízes e o destino do nazista foi à forca.

\section{REFERÊNCIAS}

ALBUQUERQUE, Hélio Cardozo de. A relação judaico-cristã: nas origens e hoje. Rio de Janeiro: Lumen Christi, 2004.

ARENDT, Hannah. Eichmann em Jerusalém: um relato sobre a banalidade do mal. Tradução Samuel Titan Jr. São Paulo: Companhia das Letras, 2013.

ARENDT, Hannah. Origens do Totalitarismo. Tradução Roberto Raposo. São Paulo: Companhia das Letras, 1989. 
ARENDT, Hannah. Eichmann em Jerusalém, um relato sobre a banalidade do mal. Tradução José Rubens Siqueira. São Paulo: Companhia das Letras, 1999.

CREUS, Carlos. Derecho Penal. Parte General. 5. ed. Buenos Aires: Astrea, 2017.

FORTES, José. A justiça e a lei na Alemanha nazista. In: FORTES, José et al. meionorte.com: blogs. [S.I.], 24 jun. 2009. Disponível em:

http://www.meionorte.com/blogs/josefortes/a-justica-e-a-lei-na-alemanha-nazista89384. Acesso em: 06 fev. 2018.

GRECO, Rogério. Curso de Direito Penal. Parte Geral. 8. ed. Rio de Janeiro: Impetus, 2007.

GOES, Marcos Paulo. "Os Protocolos dos Sábios de Sião": a fraude criada na Rússia e usada por Hitler e pela esquerda. 2015. Disponível em:

http://www.libertar.in/2015/04/os-protocolos-dos-sabios-de-siao-fraude.html. Acesso em: 05 fev. 2018.

RAFECAS, Daniel Eduardo. Aportes para un cambio cultural a partir de Auschwitz: ensayos sobre derecho, historia y educación. Buenos Aires. Biblioteca Nuestra Memoria, 2013.

RAFECAS, Daniel Eduardo. El Crimen de tortura: en el Estado autoritario y en el Estado de derecho. Buenos Aires: DIDOT, 2015.

RAFECAS, Daniel Eduardo. Historia de la Solución Final: una indagación de las etapas que llevaron al exterminio de los judíos europeos. Buenos Aires: Siglo Veintiuno Editores, 2014.

RICHARD, Lionel. A República de Weimar. São Paulo: Companhia das Letras, 1988. 